\title{
A New Species of the Genus Zhangixalus (Amphibia: Rhacophoridae) from Vietnam
}

\section{Hoa Thi NINH ${ }^{1}$, Tao Thien NGUYEN ${ }^{2, *}$, Nikolai ORLOV ${ }^{3}$, Truong Quang NGUYEN ${ }^{4} \&$ Thomas ZIEGLER ${ }^{5}$}

${ }^{1,2}$ Vietnam National Museum of Nature, Vietnam Academy of Science and Technology, 18 Hoang Quoc Viet Road, Hanoi, Vietnam.

${ }^{3}$ Department of Herpetology, Zoological Institute, Russian Academy of Sciences, 199034, St. Petersburg, Russia.

${ }^{4}$ Institute of Ecology and Biological Resources, Vietnam Academy of Science and Technology, 18 Hoang Quoc Viet Road, Hanoi, Vietnam.

${ }^{2,4}$ Graduate University of Science and Technology, Vietnam Academy of Science and Technology, 18 Hoang Quoc Viet Road, Cau Giay, Hanoi, Vietnam.

${ }^{1}$ Hanoi National University of Education, 136 Xuan Thuy Road, Cau Giay, Hanoi, Vietnam.

${ }^{5}$ AG Zoologischer Garten Köln, Riehler Strasse 173, D-50735 Cologne, Germany.

${ }^{5}$ Institute of Zoology, University of Cologne, Zülpicher Strasse 47b, D-50674 Cologne, Germany.

${ }^{*}$ Corresponding author: nguyenthientao@gmail.com

${ }^{1}$ Email:ninhhoa.hnue@gmail.com

${ }^{3}$ Email: orlov52@gmail.com

${ }^{4}$ Email: nqt2@yahoo.com

5Email: ziegler@koelnerzoo.de

\footnotetext{
${ }^{1}$ urn:1sid:zoobank.org:author:E3D33440-C302-4B3E-9309-7310A7AA77C5

${ }^{2}$ urn:1sid:zoobank.org:author:E4FE5A60-5DCF-4BA9-9837-81E83F8DE638

${ }^{3}$ urn:lsid:zoobank.org:author:73D64E77-0E78-4630-83CF-2F3423AEFF9F

${ }^{4}$ urn:1sid:zoobank.org:author:822872A6-1C40-461F-AA0B-6A20EE06ADBA

${ }^{5}$ urn:lsid:zoobank.org:author:F7B14B87-EC39-4314-82F8-1A6A250C3944
}

\begin{abstract}
We describe a new species of the genus Zhangixalus Li, Jiang, Ren \& Jiang, 2019 from Ha Giang Province, Vietnam based on morphological and molecular data. In the molecular phylogenetic analyses, the new species is nested in the Zhangixalus duboisi (Ohler, Marquis, Swan \& Grosjean, 2000) group, where it is sister to $Z$. duboisi with a genetic distance of $2.51 \%$. The new species, Zhangixalus franki sp. nov., differs from its congeners by a combination of the following morphological characters: size large, SVL 77.9-85.8 mm in males; finger webbing formula I1-1II0$1 \mathrm{III} 1 / 2-0 \mathrm{IV}$; dorsal surface of head and body green with dark brown spots; ventral surface grey or dark grey, white stripe along edge of jaw, insertion of limbs, and along lateral ridges of fore and hind limbs and flank, separating upper green part from lower grey part. The new species occurs in evergreen montane tropical forests at an elevation of ca $1300 \mathrm{~m}$ a.s.l. The new discovery brings the total number of known species in the genus Zhangixalus to 38 and the species number reported from Vietnam to nine.
\end{abstract}


Keywords. New species, Zhangixalus franki sp. nov., molecular phylogeny, taxonomy, Vietnam.

Ninh H.T., Nguyen T.T., Orlov N., Nguyen T.Q. \& Ziegler T. 2020. A New Species of the Genus Zhangixalus (Amphibia: Rhacophoridae) from Vietnam. European Journal of Taxonomy 688: 1-18. https://doi.org/10.5852/ejt.2020.688

\section{Introduction}

The family Rhacophoridae represents one of the most diverse anuran families, with 427 currently recognized species in the world (Frost 2020). Representatives of the family are distributed in Subsaharan Africa and southern Asia from Sri Lanka, Nepal and India, eastwards to Japan and southwards to Indonesia and the Philippines (Frost 2020). The genus Zhangixalus Li, Jiang, Ren \& Jiang, 2019 was recently split from Rhacophorus by Jiang et al. (2019). Zhangixalus currently contains 37 species with a distribution range of from northeastern India, Nepal, Bhutan, southern China, Myanmar, northern Thailand, Laos, northern Vietnam, Taiwan and Japan, southwards to Indonesia, Brunei and Malaysia (Frost 2020). In Vietnam, eight species have been recorded (Frost 2020), namely Z. dennysi (Blanford, 1881), Z. dorsoviridis (Bourret, 1937), Z. duboisi (Ohler, Marquis, Swan \& Grosjean, 2000), Z. dugritei (David, 1872), Z. feae (Boulenger, 1893), Z. hungfuensis (Liu \& Hu, 1961), Z. nigropunctatus (Liu, Hu \& Yang, 1962), and Z. pachyproctus (Yu, Hui, Hou, Wu, Rao \& Yang, 2019).

During our recent field work in Ha Giang Province in 2019, we collected a series of treefrogs that morphologically resembled Z. burmanus (Andersson, 1939), a species that is known from western Yunnan of China, northern Myanmar, and northeastern India (Sengupta \& Ahmed 2017). However, the newly collected specimens from Vietnam are notably larger in size than any known specimen of Z. burmanus. In addition, the specimens from Ha Giang Province differ from Z. burmanus by having ventral surface grey or dark grey; flank with a white stripe, separating upper green part from lower cream part. Furthermore, the interspecific uncorrected genetic distances (16S rRNA gene) between the new species from Ha Giang Province and other analyzed congeners varied from $2.51 \%$ to $11.57 \%$, which is higher in this study than those among recognized taxa of Zhangixalus (i.e. $1.17 \%$ between Z. duboisi and Z. omeimontis (Stejneger, 1924) or $2.40 \%$ between Z. minimus and Z. puerensis). The combination of morphological and molecular data indicate the population from Ha Giang to represent an independent evolutionary lineage that could not be assigned to any known species of Zhangixalus. Herein, we describe the Zhangixalus from Ha Giang Province, Vietnam as a new species.

\section{Material and methods}

\section{Sampling}

Field surveys were conducted from 1 to 15 June 2019 by T.T. Nguyen in Quan Ba District, Ha Giang Province, northern Vietnam. Geographic coordinates and elevations were obtained using a Garmin GPSMAP 76CSX (WGS84 datum). After photographing the frogs alive, they were euthanized in a closed vessel with a piece of cotton wool containing ethyl acetate (Simmons 2002), fixed in 80\% ethanol for five hours, and then transferred to $70 \%$ ethanol for permanent storage. Liver tissue samples were preserved separately in $70 \%$ ethanol prior to fixation. Specimens were subsequently deposited in the collections of the Vietnam National Museum of Nature (VNMN) and Institute of Ecology and Biological Resources (IEBR), Hanoi, Vietnam.

\section{Molecular data and phylogenetic analyses}

We used the protocols of Kuraishi et al. (2013), modified by Nguyen et al. (2015), for DNA extraction, amplification, and sequencing. Fragments of the mitochondrial DNA gene 16S rRNA were amplified using the primers from Kuraishi et al. (2013). 
Table 1. Samples of Zhangixalus Li, Jiang, Ren \& Jiang, 2019 and other species used for DNA analysis in this study.

\begin{tabular}{|c|c|c|c|c|c|}
\hline No. & Scientific name & Voucher & Locality & Genbank No. & Soure \\
\hline 1. & Buergeria buergeri & IABHU 41011 & Hiroshima, Japan & AB127977 & Sano et al. 2004 \\
\hline 2. & Zhangixalus burmanus & Rao6239 & Xizang, China & JX219422 & Li et al. $2012 \mathrm{~b}$ \\
\hline 3. & Z. chenfui & SCUM 060404L & Sichuan, China & EU215534 & Li et al. 2008 \\
\hline 4. & Z. chenfui & RAO ZT 0806013 & Yunnan, China & JX219431 & Li et al. $2012 \mathrm{~b}$ \\
\hline 5. & Z. dennysi & Li06 & Hunan, China & JX219433 & Li et al. $2012 \mathrm{~b}$ \\
\hline 6. & Z. dennysi & SCUM 060401L & Guangdong, China & EU215545 & Li et al. 2008 \\
\hline 7. & Z. dorsoviridis & ROM38015 & Lao Cai, Vietnam & JX219423 & Li et al. $2012 \mathrm{~b}$ \\
\hline 8. & Z. dorsoviridis & Rao060821199 & Yunnan, China & JX219426 & Li et al. 2012b \\
\hline 9. & Z. duboisi & ROM38771 & Lao Cai, Vietnam & JX219413 & Li et al. $2012 \mathrm{~b}$ \\
\hline 10. & Z. duboisi & VNMN 4103 & Lao Cai, Vietnam & LC010581 & Nguyen et al. 2017 \\
\hline 11. & Z. dugritei & LJT 060559 & Sichuan, China & JN688875 & Li et al. 2012a \\
\hline 12. & Z. dugritei & SCUM 051017 L 11 & Sichuan, China & EU215540 & Li et al. 2012a \\
\hline 13. & Z. feae & VNMN 3462 & Sa Pa, Vietnam & LC010588 & Nguyen et al. 2017 \\
\hline 14. & Z. feae & SCUM 050642W & Yunnan, China & EU215544 & Nguyen et al. 2017 \\
\hline 15. & Z. hongchibaensis & CIB 097687 & Chongqing, China & JN688883 & Li et al. 2012a \\
\hline 16. & Z. hongchibaensis & CIB 097696 & Chongqing, China & JN688882 & Li et al. 2012a \\
\hline 17. & Z. hungfuensis & SCUM 060425L & Sichuan, China & EU215538 & Li et al. 2008 \\
\hline 18. & Z. hungfuensis & SCUMLi 01 & Sichuan, China & JN688878 & Li et al. 2012a \\
\hline 19. & Z. minimus & KIZ 061214YP & Guangxi, China & EU215539 & Li et al. 2008 \\
\hline 20. & Z. minimus & KUHE:70049 & China & LC386569 & Matsui et al. 2019 \\
\hline 21. & Z. nigropunctatus & Rao3494 & Yunnan, China & JX219429 & Li et al. $2012 \mathrm{~b}$ \\
\hline 22. & Z. nigropunctatus & GZ070658 & Guizhou, China & JX219430 & Li et al. $2012 b$ \\
\hline 23. & Z. omeimontis & Li02 & Sichuan, China & JX219420 & Li et al. 2012b \\
\hline 24. & Z. smaragdinus & KIZ 06241Rao & Tibet, China & JX219411 & Li et al. $2012 \mathrm{a}$ \\
\hline 25. & Z. pinglongensis & NHMG201002011 & Guangxi, China & KU170684 & Mo et al. 2016 \\
\hline 26. & Z. pinglongensis & NHMG201002003 & Guangxi, China & KU170683 & Mo et al. 2016 \\
\hline 27. & Z. puerensis & SCUM 060649L & Yunnan, China & EU215542 & Li et al. 2012a \\
\hline 28. & Z. puerensis & ROM 37996 & Lao Cai, Vietnam & JN688891 & Li et al. 2012a \\
\hline 29. & Z. schlegelii & KUHE 44531 & Okayama, Japan & LC369670 & Matsui et al. 2019 \\
\hline 30. & Z. schlegelii & Genbank & Hiroshima, Japan & AB202078 & Sano et al. 2005 \\
\hline 31. & Z. pachyproctus & VNMN 1534 & Bac Giang, Vietnam & LC010592 & Nguyen et al. 2017 \\
\hline 32. & Z. pachyproctus & VNMN 4113 & Nghe An, Vietnam & LC010593 & Nguyen et al. 2017 \\
\hline 33. & Z. taroensis (burmanus) & SCUM 060614L & Yunnan, China & EU215537 & Li et al. 2008 \\
\hline 34. & Z. wui & CIB 097685 & Hubei, China & JN688881 & Li et al. 2012a \\
\hline 35. & Z. wui & CIB 097690 & Hubei, China & JN688880 & Li et al. 2012a \\
\hline 36. & Z. yaoshanensis & NHMG150408 & Guangxi, China & MG322122 & Chen et al. 2018 \\
\hline 37. & Z. yaoshanensis & NHMG150404 & Guangxi, China & MG322121 & Chen et al. 2018 \\
\hline 38. & Z. zhoukaiyae & AHU-RhaDb-120428 & Anhui, China & KU601502 & Pan et al. 2017 \\
\hline 39. & Z. zhoukaiyae & RhaDb-150420-02 & Anhui, China & KU601501 & Pan et al. 2017 \\
\hline 40. & Rhacophorus annamensis & VNMN 07225 & Ninh Thuan, Vietnam & LC548739 & This study \\
\hline
\end{tabular}


Table 1. Continuation

\begin{tabular}{llllll}
\hline No. & Scientific name & Voucher & Locality & Genbank No. & Soure \\
\hline 41. & R. annamensis & HAO 01 & Ninh Thuan, Vietnam & LC548740 & This study \\
42. & R. kio & VN.2018.057 & Kon Tum, Vietnam & LC548742 & This study \\
43. & R. kio & VN.2018.082 & Kon Tum,Vietnam & LC548741 & This study \\
44. & R. orlovi & TQ.2018.20 & Tuyen Quang, Vietnam & LC548743 & This study \\
45. & R. orlovi & TQ.2018.56 & Tuyen Quang, Vietnam & LC548744 & This study \\
46. $\begin{array}{l}\text { Zhangixalus franki } \\
\text { sp. nov }\end{array}$ & VNMN 011686 & Ha Giang, Vietnam & LC548745 & This study \\
47. $\begin{array}{l}\text { Zhangixalus franki } \\
\text { sp. nov }\end{array}$ & VNMN 011687 & Ha Giang, Vietnam & LC548746 & This study \\
\hline
\end{tabular}

For the phylogenetic analyses, sequences of 21 species of Zhangixalus and three species of Rhacophorus from previous studies were used in combination with a sequence of Buergeria buergeri (Temminck \& Schlegel, 1838) as an outgroup (Table 1).

Chromas Pro software (Technelysium Pty Ltd., Tewantin, Australia) was used to edit the sequences, which were aligned using MAFFT version 7 (Katoh \& Standley 2013) with default settings. We then checked the initial alignments by eye and adjusted slightly. Phylogenetic trees were constructed by using maximum likelihood (ML) and Bayesian inference (BI). Prior to ML and BI analyses, we chose the optimum substitution models for all sequences using Kakusan 4 (Tanabe 2011) based on the Akaike information criterion (AIC). The best model selected for ML was the general time reversible model (GTR: Tavaré 1986) with a gamma shape parameter (G: 0.220 in ML and 0.248 in BI). The BI summarized two independent runs of four Markov Chains for 10000000 generations. A tree was sampled every 100 generations and a consensus topology was calculated for 70,000 trees after discarding the first 30001 trees (burn-in 1000000 ). We checked parameter estimates and convergence using Tracer version 1.5 (Rambaut \& Drummond 2009). The strength of nodal support in the ML tree was analyzed using nonparametric bootstrapping (MLBS) with 1,000 replicates. We regarded tree nodes in the ML tree with bootstrap values of $75 \%$ or greater as sufficiently resolved (Huelsenbeck \& Hillis 1993), and nodes with a Bayesian Posterior Probability (BPP) of $95 \%$ or greater as significant in the BI analysis (Leaché \& Reeder 2002). Pairwise comparisons of uncorrected sequence divergences (p-distance) were calculated for the 16S rRNA fragments only between species of the genus Zhangixalus.

\section{Morphological characters}

A total of 36 measurements was taken with a dial caliper to the nearest $0.1 \mathrm{~mm}$ following the methods in Nguyen et al. (2016). Abbreviations are as follows:

\begin{tabular}{|c|c|c|}
\hline DAE & $=$ & Distance between anterior corners of eyes \\
\hline DPE & $=$ & Distance between posterior corners of eyes \\
\hline ED & $=$ & Eye diameter \\
\hline EN & $=$ & Distance from anterior corner of eye to nostril \\
\hline $\mathrm{fd} 3$ & $=$ & width of disc of finger III \\
\hline FeL & $=$ & Thigh length, from vent to knee \\
\hline Fig 1-4 & $=$ & Length of fingers I-IV, from base of finger to tip of finger \\
\hline FLL & $=$ & Upper arm length, from axilla to elbow \\
\hline FoL & $=$ & Foot length, from tibiotarsal joint to tip of fourth toe \\
\hline HAL & $=$ & Forearm length, from elbow to tip of third finger \\
\hline
\end{tabular}




$\begin{array}{ll}\text { HL } & =\text { Head length, from back of mandible to tip of snout } \\ \text { HW } & =\text { Maximum head width across angle of jaws } \\ \text { IMT } & =\text { Inner metatarsal tubercle length } \\ \text { IN } & \text { Internarial distance } \\ \text { IPT } & \text { Inner palmar tubercle length } \\ \text { IOD } & =\text { Interorbital distance, minimal distance between orbits } \\ \text { MBE } & =\text { Distance from back of mandible to back of eye } \\ \text { MFE } & =\text { Distance from back of mandible to front of eye } \\ \text { MN } & =\text { Distance from jaw angle to nostril } \\ \text { NS } & =\text { Distance from nostril to tip of snout } \\ \text { SNL } & =\text { Snout length, from anterior corner of eye to tip of snout } \\ \text { SVL } & =\text { Snout-vent length } \\ \text { TbL } & =\text { Tibia length, from knee to tibiotarsal joint } \\ \text { TbW } & =\text { Maximal tibia width } \\ \text { td4 } & =\text { Width of disc of toe } 4 \\ \text { Toe 1-5 } & =\text { Length of toes I-V from inner metatarsal tubercle to tip of toe } \\ \text { TYD } & =\text { Maximal tympanum diameter } \\ \text { TYE } & =\text { Distance from anterior margin of tympanum to posterior corner of eye } \\ \text { UEW } & =\text { Maximum width of upper eyelid. }\end{array}$

Terminology for describing webbing formula followed Glaw and Vences (2007). Sex was determined by the presence of nuptial pads and gonadal inspection.

We compared morphological characters of the new species with congeners from Vietnam and China based on specimen examination (see Appendix) and data obtained from the literature (e.g., Stejneger 1907; Bourret 1937; Liu 1950; Liang \& Wang 1978; Maeda \& Matsui 1990; Lue et al. 1995; Ohler et al. 2000; Orlov et al. 2001; Harvey et al. 2002; Wilkinson 2003; Bain \& Nguyen 2004; Goris \& Maeda 2004; Wilkinson \& Rao 2004; Rao et al. 2006; Bordoloi et al. 2007; Chou et al. 2007; Ohler 2009; Fei et al. 2010; Li et al. 2012a; Ziegler et al. 2014; Jiang et al. 2016; Mo et al. 2016; Liu et al. 2017; Pan et al. 2017; Chen et al. 2018; Yu et al. 2019).

\section{Results}

\section{Phylogenetic analyses}

Aligned, combined sequences yielded a total of 1,085 nucleotide sites. Of 1,085 nucleotide sites, 304 were variable and 266 were parsimony informative within the in-group. Nucleotide frequencies were $\mathrm{A}=$ $37.0 \%, \mathrm{~T}=24.4 \%, \mathrm{C}=20.9 \%$, and $\mathrm{G}=17.7 \%$ (data for ingroup only). The ML and $\mathrm{BI}$ analyses produced similar topologies with $-\operatorname{lnL}=7372.186$ and 7549.990 respectively. Phylogenetic analyses employing ML and BI methods yielded identical topologies, and only the BI tree is presented in Figure 1.

Monophyly of Zhangixalus with respect to the outgroup species was fully supported (each $100 \%$ support in ML bootstrap value and Bayesian posterior probability) and samples were split into two major clades, Rhacophorus and Zhangixalus. The clade Zhangixalus contained 21 taxa and was comprised of four subclades A1, A2, A3 and A4. The subclade A1 contained Z. burmanus, Z. dorsoviridis, Z. duboisi, $Z$. omeimontis, Z. zhoukaiyae and the new species from Ha Giang Province with strong support values $(\mathrm{MLBS}=83 \%, \mathrm{BPP}=1.00)($ Fig. 1$)$.

The mean interspecific uncorrected genetic p-distances for the 16S rRNA gene fragment examined between the unnamed Zhangixalus species from Ha Giang and other known congeners ranged from $2.51 \%$ (compared with Z. duboisi) to $11.57 \%$ (compared with Z. smaragdinus). In the genus Zhangixalus, the 


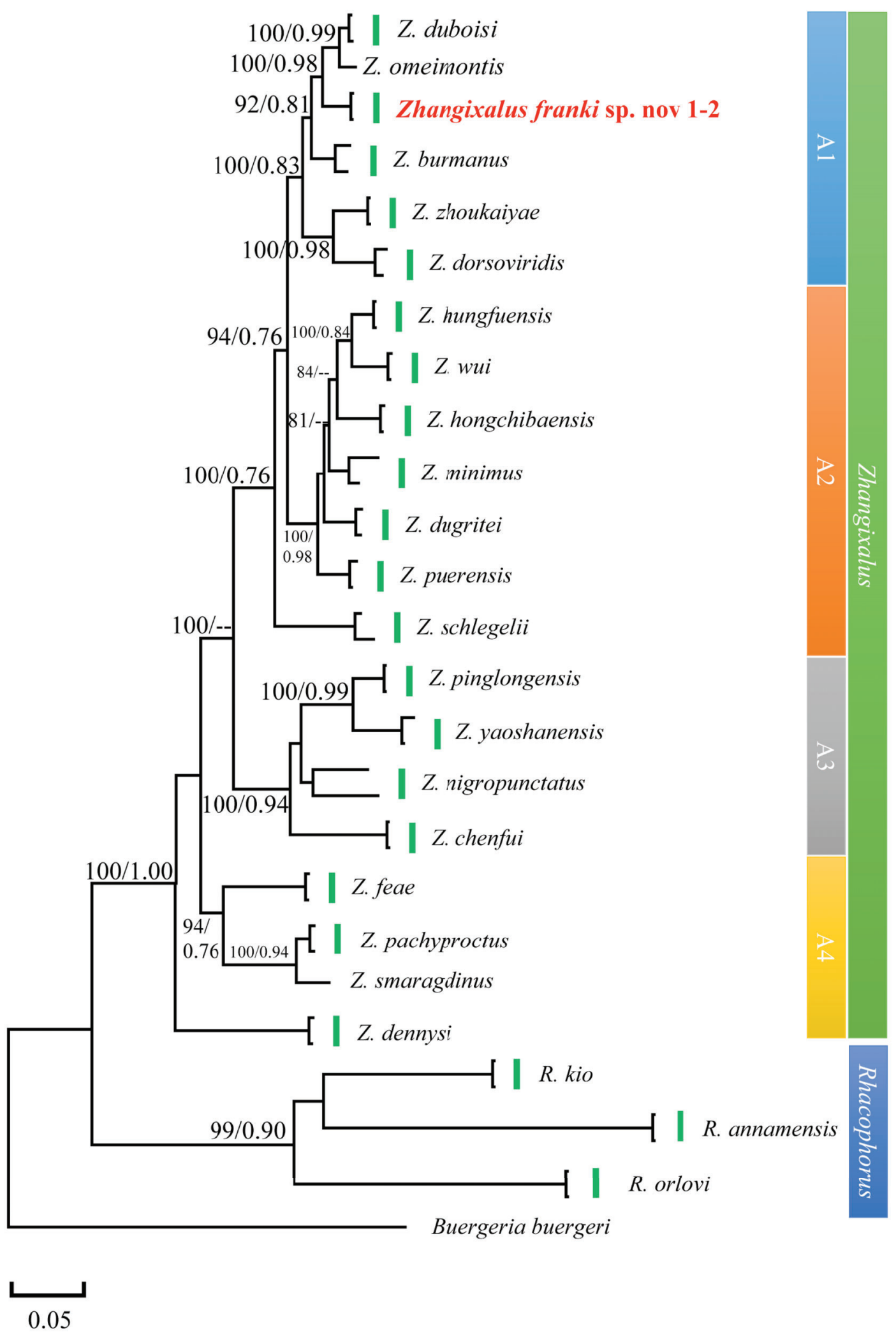

Fig. 1. BI tree from a 1085 bp sequence of mitochondrial 16S rRNA gene of Zhangixalus Li, Jiang, Ren \& Jiang, 2019 and outgroup species. Numbers above and below branches are Bayesian posterior probabilities (BPP) and ML bootstrap values (only values above $60 \%$ are shown), respectively. For GenBank accession numbers, refer to Table 1. 
lowest mean genetic distance was between $Z$. duboisi and Z. omeimontis at approximately $1.17 \%$. Two other taxa, Z. minimus and Z. puerensis, showed a genetic distance of approximately $2.40 \%$ (Table 2 ). Furthermore, it is also clearly separated morphologically from all nominal species of Zhangixalus. Thus, we describe the population of Zhangixalus. Therefore consider the unnamed species of Zhangixalus from Ha Giang Province as a distinct species and describe it in the following.

Class Amphibia Gray, 1825

Order Anura Fischer von Waldheim, 1813

Family Rhacophoridae Hoffman, 1932

Genus Zhangixalus Li, Jiang, Ren \& Jiang, 2019

Zhangixalus franki sp. nov.

urn:lsid:zoobank.org:act:346FA039-3D9A-4F41-A4F2-57F5E7ABA793

Fig. 2

\section{Diagnosis}

The new species can be assigned to the genus Zhangixalus based on the following morphological characters: snout pointed; presence of intercalary cartilage between terminal and penultimate phalanges of digits, distal end of terminal phalanx in Y-shape; tips of digits expanded into large disks, bearing
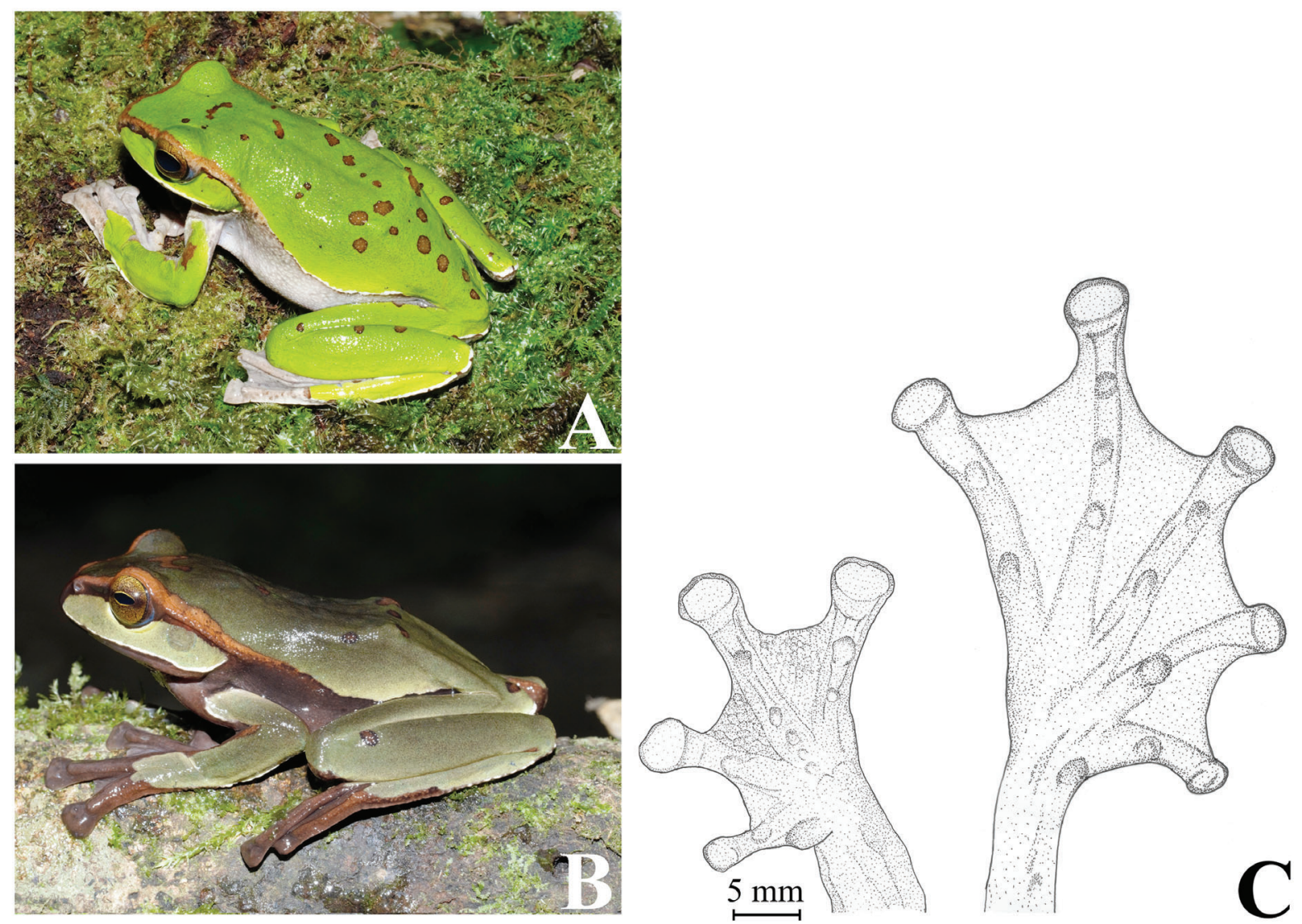

Fig. 2. A-B. Dorsal and lateral views. C. Drawing of ventral view of left hand and right foot of the adult male holotype (VNMN 011682) of Zhangixalus franki sp. nov. from Quan Ba District, Ha Giang Province, northern Vietnam. 


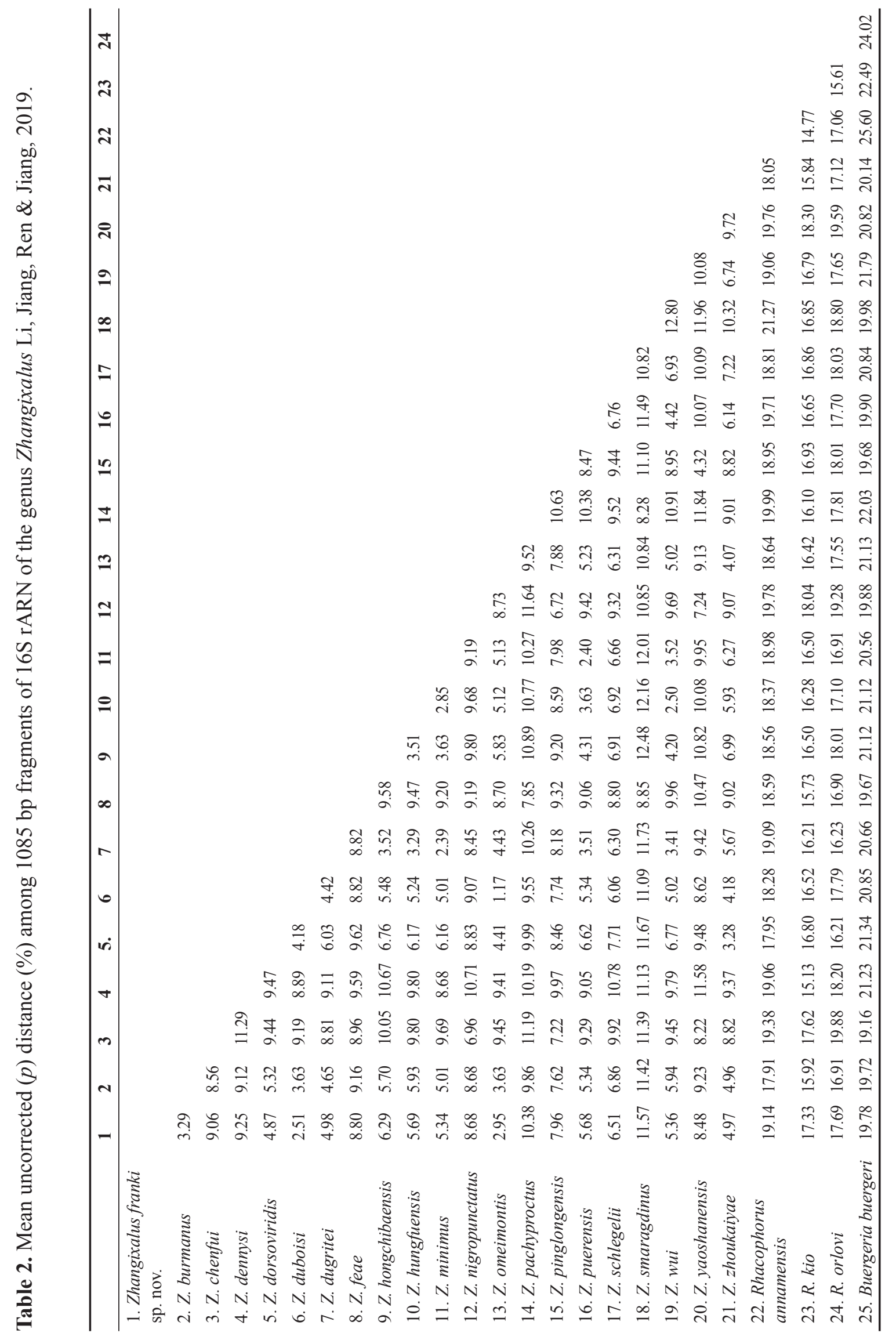


circum-marginal grooves; fingers webbed; presence of supra-cloacal dermal ridge; and pupil horizontal (Jiang et al. 2019). In addition, the new species is unambiguously nested in the genus Zhangixalus by molecular phylogenetic evidence. It is closely related to $Z$. duboisi and Z. omeimontis and nested in the same clade with Zhangixalus dugritei (David, 1872), the type species of this genus.

The new species is distinguished from its congeners by a combination of the following morphological characters: 1) size large (SVL 77.9-85.8 $\mathrm{mm}$ for the males); 2) head slightly wider than long; 3) snout pointed; 4) dorsal skin smooth; 5) finger webbing formula I1-1II0-1III $1 / 2-0 I V$; 6) dorsal surface of head and body green with dark brown spots; 7) lower jaw region greyish, throat, chest and belly white; 8) white stripe along edge of jaw, insertion of limbs, and along lateral ridges of fore limbs, hind limbs and flank, separating upper green part from lower grey part.

\section{Etymology}

We name this new species in honor of Dr Frank Mutschmann, late amphibian veterinarian and conservationist from Berlin, Germany, in recognition of his support of our amphibian research and conservation projects in Vietnam. As common names we suggest Frank's Tree Frog (English), Êch cây frank (Vietnamese) and Franks Ruderfrosch (German).

\section{Material examined}

\section{Holotype}

VIETNAM • adult ${ }^{\lambda}$; northern Vietnam, Ha Giang Province, Quan Ba District, in the forest of Tung Vai Commune; 23002'45" N, 104050'59" E; elevation 1360 m a.s.1.; 11 Jun. 2019; collected by T.T. Nguyen; VNMN 011682.

\section{Paratypes}

VIETNAM $\bullet 4$ adult $\widehat{\partial} \widehat{\jmath}$; same data as for holotype; 13 Jun. 2019; collected by T.T. Nguyen; VNMN 011683, VNMN 011684, IEBR A.2019.7-A.2019.8 (VNMN 011685, VNMN 011686) and one sub-adult VNMN 011687.

\section{Description of holotype}

SizE. Large, body robust (SVL $82.8 \mathrm{~mm}$ ).

HEAD. Slightly compressed, wider than long (HW $26.5 \mathrm{~mm}$, HL $25.7 \mathrm{~mm}$ ), convex above; snout pointed, slightly protruding beyond lower jaw in lateral view, and longer than horizontal diameter of eye (SNL $11.6 \mathrm{~mm}$, ED $8.2 \mathrm{~mm}$ ).

CANTHUS RostRalis. Rounded, loreal region oblique, concave; interorbital distance greater than internarial distance and upper eyelid width (IOD $9.2 \mathrm{~mm}$, IN $8.1 \mathrm{~mm}$, UEW $6.2 \mathrm{~mm}$ ); distance between anterior corners of eyes approximately $69 \%$ of distance between posterior corners of eyes.

NostriLs. Round, without lateral flap of skin, closer to tip of snout than to eye.

PupIL. Oval, horizontal.

Tympanum. Distinct, round, about half of eye diameter, and two times greater than distance between tympanum and eye.

Pineal ocellus. Absent; spinules on upper eyelid absent; vomerine teeth well developed, in two oblique ridges. 
ChoAnae. Round.

Tongue. Deeply notched posteriorly; supratympanic fold distinct, extending from behind eye to beyond level of axilla.

FoRELIMBS. Upper arm short, about one third of forearm length (FLL $14.7 \mathrm{~mm}$, HAL $41.7 \mathrm{~mm}$ ), dermal fringe present along outer edge of forearm; not well developed; relative finger lengths $\mathrm{I}<\mathrm{II}<\mathrm{V}<\mathrm{III}$; tips of fingers with enlarged discs with distinct circum-marginal grooves, disc of finger III approximately 1.5 times width of finger III (fd3/fw3 1.5), greater than tympanum diameter (fd3/TYD 1.27); webbing formula I1-1II0-1III $1 / 2-0 I V$; subarticular tubercles distinct, blunt, round, formula 1, 1, 2, 2.

HiNDLimBs. Heels overlapping when held at right angles to body; tibia length about five times greater than tibia width (TbL $39.3 \mathrm{~mm}$, TbW $8.5 \mathrm{~mm}$ ), longer than thigh length (FeL $34.1 \mathrm{~mm}$ ), shorter than foot length (FoL $53.4 \mathrm{~mm}$ ); relative toe lengths $\mathrm{I}<\mathrm{II}<\mathrm{III}<\mathrm{V}<\mathrm{IV}$; tips of toes with enlarged discs with distinct circum-marginal grooves, discs slightly smaller than those of fingers; webbing formula I0-0II0- $1 / 2 \mathrm{III} 0$ 1IV0-0V; subarticular tubercles distinct, blunt, round, formula 1, 1, 2, 3, 2; inner metatarsal tubercle small (IMT $3.2 \mathrm{~mm}$ ); dermal ridge present along outer edge of tibia and tarsus; dermal projection present at tibiotarsal articulation.

SKIN TEXTURE. Dorsal surface of head and body smooth, canthal and supratympanic folds on each side developed, throat and chest smooth, belly rough, ventral surface of fore and hind limbs smooth, a short dermal appendage above vent.

COLORATION IN LIFE. Iris bronze, pupil black; dorsal surface of head and body green with some small dark brown spots, various in size and shape; tympanum region green or dark green; a yellowish brown stripe running from tip of snout, along canthus rostralis, bordering upper eyelid, along supratympanic fold to posterior of axilla; dorsal surface of fore and hind limbs green, fingers and toes grey; axilla, lower part of flank and belly grey; white stripe present along edge of upper jaw, limb insertions, and dermal fringes of fore and hind limbs; flank with white stripe, separating upper green part from lower grey part; ventral surface of arm and thigh grey; anterior and posterior parts of thigh and ventral surface of tibia grey; lower jaw and throat region grey; supracloacal area grey; ventral side of webbing greyish brown, nuptial pad grey. Color can change from green to dark green depending on activity and environmental conditions.

Coloration IN PRESERVATIVE. As in life, but with green dorsal surface fading to blue and cream white ventral surface fading to greyish brown, brown line extending from tip of snout to axilla.

Male SeCONDARY SeXual CHARActers. Male specimens with smooth oval nuptial pad on prepollex and inner edge of finger I, and a subgular vocal sac.

\section{Variation of paratypes}

The ground color of dorsum is dark green or green, ventral surface is grey or greyish brown. The number of dark brown spots on dorsum ranges from 9 to 45 , variable in size and shape. For measurements of type series see Table 3 .

\section{Comparisons}

In the following, we compared the new species with other members of Zhangixalus distributed in Vietnam and neighboring countries.

Zhangixalus franki sp. nov can be distinguished from the following 29 species in the genus Zhangixalus by having a larger size in males (SVL 77.9-85.8) versus Z. achantharrhena at 36.52-40.56 mm (Harvey 
Table 3. Measurements (in mm) of Zhangixalus franki sp. nov.

\begin{tabular}{|c|c|c|c|c|c|c|c|}
\hline Field no & $\begin{array}{l}\text { VNMN } \\
011682\end{array}$ & $\begin{array}{l}\text { VNMN } \\
011683\end{array}$ & $\begin{array}{l}\text { VNMN } \\
011684\end{array}$ & $\begin{array}{l}\text { VNMN } \\
011685\end{array}$ & $\begin{array}{l}\text { VNMN } \\
011686\end{array}$ & $\begin{array}{l}\text { Mean }+ \text { SD } \\
(n=5 \text { males })\end{array}$ & $\begin{array}{l}\text { VNMN } \\
011687\end{array}$ \\
\hline Type status & Holotype & Paratype & Paratype & Paratype & Paratype & & Paratype \\
\hline Sex & M (adult) & M (adult) & M (adult) & M (adult) & M (adult) & & M (subadult) \\
\hline SVL & 82.8 & 85.8 & 82.3 & 79.7 & 77.9 & $81.7 \pm 3.01$ & 61.9 \\
\hline HW & 26.5 & 27.9 & 27.5 & 26.2 & 25.1 & $26.6 \pm 1.12$ & 23.1 \\
\hline HL & 25.7 & 27.2 & 26.7 & 26.0 & 24.6 & $26.0 \pm 1.01$ & 22.0 \\
\hline $\mathrm{MN}$ & 21.7 & 23.1 & 22.4 & 21.7 & 21.1 & $22.0 \pm 0.77$ & 18.6 \\
\hline MFE & 16.6 & 17.4 & 17.0 & 16.3 & 16.5 & $16.8 \pm 0.45$ & 14.1 \\
\hline MBE & 9.8 & 10.0 & 9.3 & 9.5 & 9.6 & $9.6 \pm 0.27$ & 8.2 \\
\hline SNL & 11.6 & 13.1 & 12.2 & 11.9 & 11.8 & $12.1 \pm 0.58$ & 9.7 \\
\hline ED & 8.2 & 8.6 & 9.5 & 8.6 & 8.1 & $8.6 \pm 0.54$ & 6.9 \\
\hline UEW & 6.2 & 7.3 & 7.1 & 7.1 & 6.5 & $6.8 \pm 0.47$ & 6.1 \\
\hline IN & 8.1 & 7.6 & 7.2 & 7.7 & 7.7 & $7.6 \pm 0.30$ & 7.5 \\
\hline IOD & 9.2 & 10.5 & 8.9 & 10.0 & 9.3 & $9.6 \pm 0.67$ & 8.2 \\
\hline DAE & 16.3 & 17.7 & 16.7 & 17.0 & 15.7 & $16.7 \pm 0.76$ & 13.2 \\
\hline DPE & 23.6 & 24.3 & 24.3 & 22.8 & 22.9 & $23.6 \pm 0.74$ & 20.6 \\
\hline NS & 5.4 & 5.3 & 5.1 & 5.1 & 5.0 & $5.2 \pm 0.17$ & 4.8 \\
\hline EN & 6.9 & 7.5 & 6.8 & 6.7 & 6.6 & $6.9 \pm 0.34$ & 5.5 \\
\hline TYD & 4.5 & 4.8 & 5.4 & 5.1 & 5.0 & $4.9 \pm 0.33$ & 3.9 \\
\hline TYE & 2.2 & 4.5 & 2.1 & 2.1 & 1.9 & $2.6 \pm 1.09$ & 2.0 \\
\hline FLL & 14.7 & 14.0 & 15.6 & 12.9 & 13.8 & $14.2 \pm 1.00$ & 11.6 \\
\hline HAL & 41.7 & 44.1 & 40.4 & 40.0 & 40.9 & $41.4 \pm 1.62$ & 34.0 \\
\hline IPT & 5.2 & 5.2 & 5.4 & 5.6 & 5.3 & $5.3 \pm 0.15$ & 3.6 \\
\hline Fig 1 & 8.3 & 9.0 & 9.4 & 7.7 & 8.2 & $8.5 \pm 0.66$ & 6.3 \\
\hline Fig 2 & 13.0 & 13.3 & 14.0 & 12.2 & 13.5 & $13.2 \pm 0.66$ & 10.8 \\
\hline Fig 3 & 18.6 & 19.6 & 18.6 & 18.2 & 17.3 & $18.4 \pm 0.84$ & 14.4 \\
\hline Fig 4 & 14.8 & 15.4 & 15.6 & 14.0 & 14.9 & $14.9 \pm 0.64$ & 12.4 \\
\hline $\mathrm{fd} 3$ & 5.7 & 6.2 & 5.6 & 5.3 & 6.2 & $5.8 \pm 0.39$ & 5.0 \\
\hline FeL & 34.1 & 35.7 & 36.7 & 35.6 & 36.4 & $35.7 \pm 0.99$ & 29.3 \\
\hline TbL & 39.3 & 39.7 & 37.4 & 38.4 & 38.3 & $38.6 \pm 0.90$ & 33.6 \\
\hline TbW & 8.5 & 9.3 & 9.1 & 8.7 & 8.9 & $8.9 \pm 0.34$ & 5.9 \\
\hline FoL & 53.4 & 54.9 & 50.8 & 50.7 & 51.0 & $52.2 \pm 1.90$ & 43.6 \\
\hline Toe 1 & 14.1 & 14.5 & 13.1 & 13.8 & 11.9 & $13.5 \pm 1.01$ & 11.9 \\
\hline Toe 2 & 20.7 & 21.2 & 19.8 & 20.4 & 18.1 & $20.0 \pm 1.18$ & 16.5 \\
\hline Toe 3 & 29.0 & 29.6 & 27.3 & 27.5 & 24.9 & $27.7 \pm 1.81$ & 22.9 \\
\hline Toe 4 & 36.3 & 36.3 & 35.5 & 34.4 & 34.8 & $35.4 \pm 0.86$ & 28.3 \\
\hline Toe 5 & 31.2 & 31.4 & 30.5 & 30.3 & 29.7 & $30.6 \pm 0.68$ & 25.3 \\
\hline $\mathrm{td} 4$ & 4.6 & 5.0 & 4.4 & 4.6 & 3.2 & $4.4 \pm 0.68$ & 4.2 \\
\hline IMT & 3.2 & 3.6 & 3.5 & 3.3 & 2.1 & $3.1 \pm 0.61$ & 2.4 \\
\hline
\end{tabular}


et al. 2002); Z. arboreus at 42-60 mm (Wilkinson 2003); Z. arvalis at 39-46.4 $\mathrm{mm}$ (Lue et al. 1995); Z. aurantiventris at 48-54 mm (Lue et al. 1994); Z. chenfui at 33-41 $\mathrm{mm}$ (Fei et al. 2010); Z. dorsoviridis (Bourret, 1937) at 31.31-2.43 mm (Orlov et al. 2001); Z. dugritei at 31.65-47 mm (Liu 1950; Orlov et al. 2001; Fei et al. 2010); Z. dulitensis at 38.39-39.66 mm (Harvey et al. 2002); Z. hongchibaensis at 46.5-49.7 $\mathrm{mm}$ (Li et al. 2012a); Z. hungfuensis at 31-37 mm (Fei et al. 2010) Z. jarujini at 33.7$40 \mathrm{~mm}$ (Fei et al. 2010); Z. leucofasciatus at 35-48 mm (Fei et al. 2010); Z. lishuiensis at 34.2-35.8 mm (Liu et al. 2017); Z. minimus at 21.3-33.0 mm (Rao et al. 2006); Z. moltrechti at 33-46 mm (Fei et al. 2010); Z. nigropunctatus at 32-37 $\mathrm{mm}$ (Fei et al. 2010); Z. owstoni at $42-51 \mathrm{~mm}$ (Maeda \& Matsui 1990); Z. pinglongensis at 32.0-38.5 mm (Mo et al. 2016); Z. prasinatus at 49-56 mm (Fei et al. 2010); Z. prominanus at 50.46-51.26 mm (Harvey et al. 2002); Z. puerensis at 35.5-41 $\mathrm{mm}$ (Bain \& Nguyen 2004); Z. schlegelii at $49 \mathrm{~mm}$ (Stejneger 1907); Z. suffry at 38.5-52.9 mm (Bordoloi et al. 2007); Z. taipeianus at 30.7-36.7 mm (Liang \& Wang 1978); Z. viridis at 45-56 mm (Goris \& Maeda 2004); Z. wui at 35.2-38.2 $\mathrm{mm}$ (Li et al. 2012a); Z. yaoshanensis at 31.6-36.4 mm (Chen et al. 2018); Z. yinggelingensis at 43-43.4 mm (Chou et al. 2007); Z. zhoukaiyae at 27.9-36.88 $\mathrm{mm}$ (Pan et al. 2017).

Zhangixalus franki sp. nov. differs from the following seven species by having dorsum smooth; dorsal surface green with some small dark spots; chest and belly grey; supratympanic fold well developed, brown or gold; white stripe along lateral ridges of fore and hind limbs and flank, separating upper green part from lower grey part; and webbing between fingers incomplete verses dorsum of $Z$. duboisi green and brown, skin granular with horny spinules, venter fleshy with brown spots (Ohler et al. 2000); snout of $Z$. hui yellowish brown (Li et al. 2012a); dorsum and dorsal aspect of limbs of $Z$. omeimontis green with large brown markings (Liu 1950), supratympanic fold of $Z$. pachyproctus, Z. smaragdinus and Z. dennysi green and weakly developed (Yu et al. 2019; Fei et al. 2010); lateral ridges of fore and hind limbs and flank of $Z$. dennys $i$ without white stripe; supratympanic fold yellow and webbing between fingers complete in Z. feae (Ziegler et al. 2014).

The new species mostly resembles $Z$. burmanus, but with clearly distinguishing characters: males of Zhangixalus franki sp. nov. with SVL at 77.9-85.5 mm larger than those of Z. burmanus with SVL at 47-70.5 (Ohler 2009; Jiang et al. 2016; Wilkinson \& Rao 2004); webbing between fingers in males of Zhangixalus franki sp. nov. is more developed than that in males of $Z$. burmanus (I1-1II0-1III $1 / 2-0 I V$ vs I1-1 1/4II1-21/2III1-1IV in Z. burmanus Ohler 2009); color on upper and, lower parts of flank separated from each other by white line, and dark spots on anterior and posterior sides of thigh are absent in Zhangixalus franki sp. nov. whereas, dark brown spots enclosing cream spots on flanks and thigh present in Z. burmanus (Wilkinson \& Rao 2004).

\section{Distribution}

Zhangixalus franki sp. nov. is currently known only from the type locality in Ha Giang Province, northern Vietnam (Fig. 3). The species was recorded at elevations between 1320 and $1360 \mathrm{~m}$ a.s.1.

\section{Natural history}

Specimens of the new species were collected from 19:00 to 24:00 on trees, close to small ponds in undisturbed evergreen forest (Fig. 4). Other tree frogs that were found at the same site were Polypedates sp. (of the P. leucomystax species complex), Z. duboisi and Kurixalus sp. Females, larval stages and eggs of the new species are unknown.

\section{Conservation status}

The new species is expected to be found in evergreen forests of Guangxi Province, southern China. However, the actual distributional range should be confirmed in further studies. Given the available information, we suggest this species be considered as Data Deficient following IUCN's Red List categories (IUCN 2020). 


\section{Discussion}

Ziegler et al. (2014) reported Z. feae for the first time from Ha Giang Province, northern Vietnam based a photograph which was taken at the type locality of Z. franki. Although the voucher specimen is not available, the color pattern of the individual in Ziegler et al. (2014) agreed well with the new species (dorsal surface green with some dark spots; a golden stripe running from tip of snout, along canthus rostralis, bordering

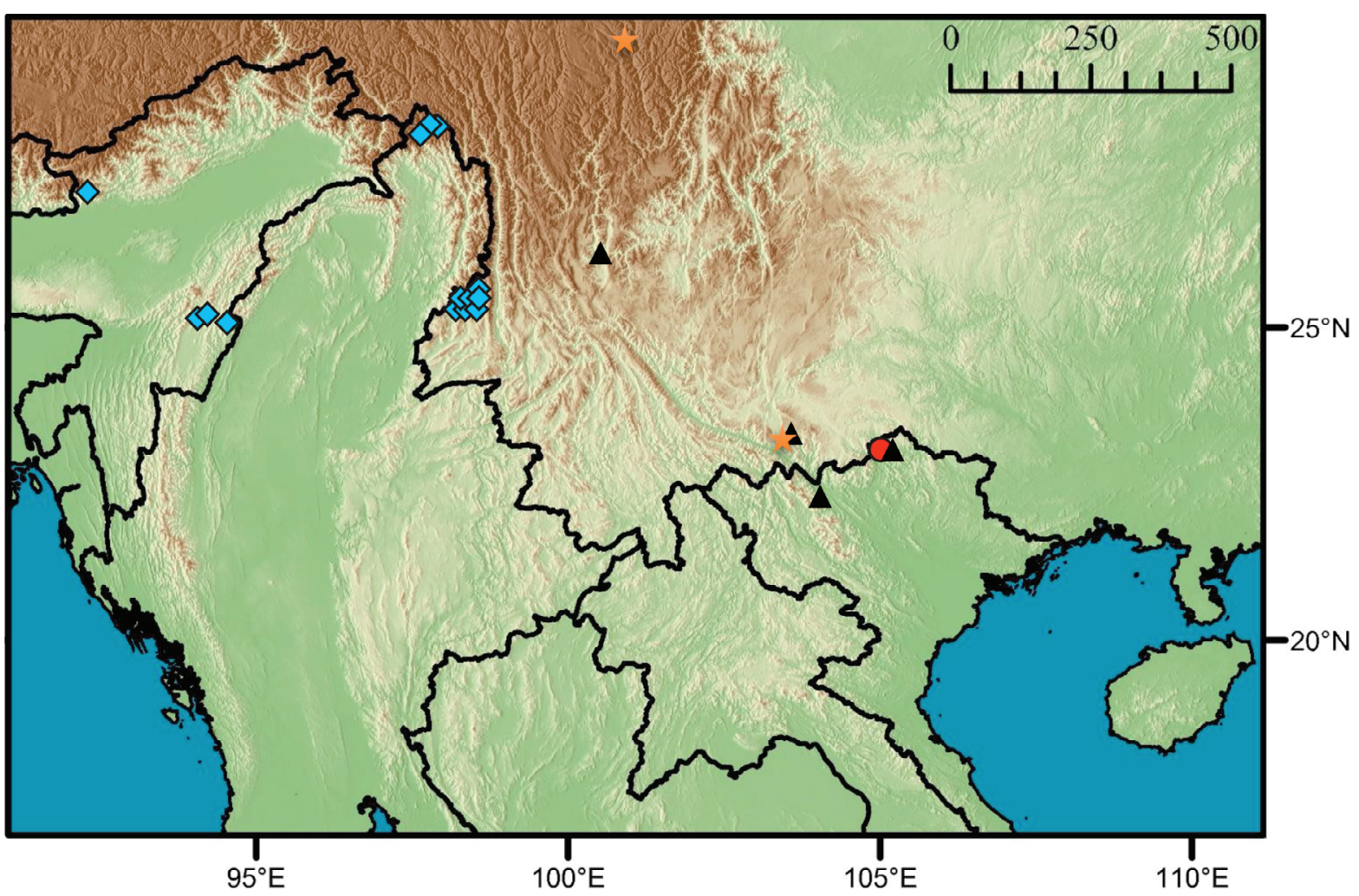

Fig. 3. Map showing the type locality of Zhangixalus franki sp. nov. (0) in Quan Ba District, Ha Giang Province, northern Vietnam and distribution of Z. burmanus (Andersson, 1939) ( $\diamond), Z$. duboisi (Ohler, Marquis, Swan \& Grosjean, 2000) ( $\mathbf{\Delta}$ ) and Z. omeimontis (Stejneger, 1924) ( $\star$ orange star).
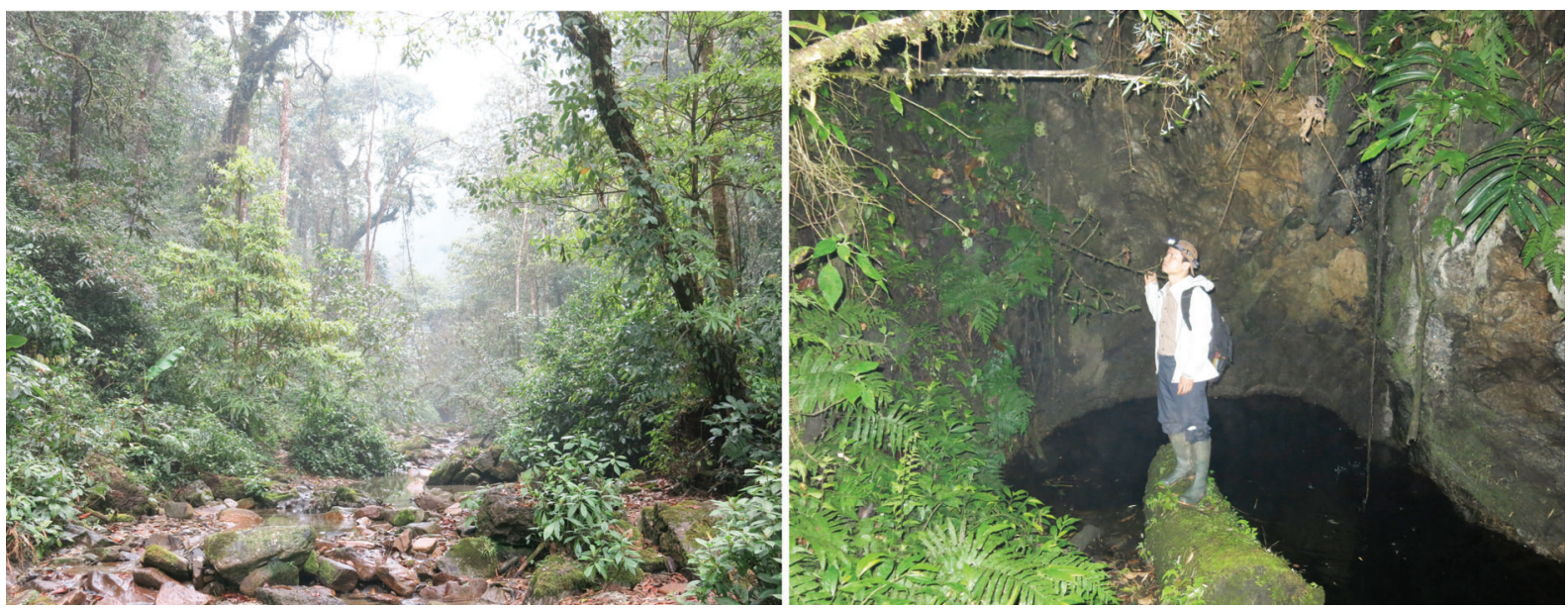

Fig. 4. Habitat of Zhangixalus franki sp. nov. at the type locality in Quan Ba District, Ha Giang Province, Vietnam. 
upper eyelid, and along supratympanic fold to shoulder; white stripes present along upper jaw, dermal fringes of fore and hind limbs, as well as along flank; webbing grey). Therefore the previous record of Z. feae in Ha Giang Province by Ziegler et al. (2014) should be re-identified as Z. franki. In our phylogenetic analyses, $Z$. franki was clustered in the same clade with Z. burmanus, Z. dorsoviridis, Z. duboisi, Z. omeimontis, and $Z$. zhoukaiyae, whereas Z. feae was embedded in the same clade with $Z$. smaragdinus and $Z$. dennysi. The discovery of $Z$. franki from Ha Giang Province brings the total number of known species in the genus Zhangixalus to 37 and the species number reported from Vietnam to nine (Frost 2020).

Tropical montane forests in the border region between Vietnam and China are known to harbor a high level of species richness and local endemism (Sterling et al. 2006). One of the main reasons assumed to be responsible for this richness is greater environmental heterogeneity observed in the montane regions as opposed to the lowland regions, allowing for a larger number of habitats to be occupied by species (Keller et al. 2009). Therefore it is not unexpected that new species from this region are still being discovered and further studies in this region are required to discover the actual species richness of tree frogs in Vietnam.

\section{Acknowledgements}

We are grateful to the directorates of the Forest Protection Department of Ha Giang Province for support of our field work and issuing relevant permits. We thank M.V. Le and the staff of Tung Vai for their assistance in the field. We thank E. Sterling (New York) and K. Koy (Berkeley) for providing the map. Research of T.T. Nguyen is funded by the Vietnam National Foundation for Science and Technology Development (NAFOSTED) under Grant Number 106.05-2019.334. Field work in Ha Giang Province was partially funded by the Nagao Natural Environment Foundation (NEF) Commemorative Grant Fund for Capacity Building of Young Scientists - CGF Programme for T. T. Nguyen, RFBR grants 19-5453010 and 19-54-54003 - Vietnam for N. Orlov in frame of state theme AAAA-A19-119082990107-3.

\section{References}

Bain R.H. \& Nguyen T.Q. 2004. Herpetofaunal diversity of Ha Giang Province in northeastern Vietnam, with descriptions of two new species. American Museum Novitates 2004 (3453): 1-42.

Bordoloi S., Bortamuli T. \& Ohler A. 2007. Systematics of the genus Rhacophorus (Amphibia, Anura): identity of red-webbed forms and description of a new species from Assam. Zootaxa 1653: 1-20. https://doi.org/10.5281/zenodo.179813

Bourret R. 1937. Notes herpétologiques sur l'Indochine française. XIV. Les Batraciens de la Collection du Laboratoire des Sciences naturelles de l'Université. Descriptions de quinze espèces ou variétés nouvelles. Annexe au Bulletin Général de 1'Instruction Publique 56. Gouvernement Général De L'Indochine, Hanoi.

Chen W., Liao X., Zhou S., Mo Y. \& Huang, Y. 2018. Rediscovery of Rhacophorus yaoshanensis and Theloderma kwangsiensis at their type localities after five decades. Zootaxa 4379 (4): 484-496.

https://doi.org/10.11646/zootaxa.4379.4.2

Chou W.H., Lau M.W. \& Chan B.P.L. 2007. A new treefrog of the genus Rhacophorus (Anura: Rhacophoridae) from Hainan Island, China. Raffles Bulletin of Zoology 55: 157-165.

Fei L., Ye C.Y. \& Jiang J.P. 2010. Colored atlas of Chinese amphibians. Sichuan Publishing House of Science and Technology, Chengdu.

Frost D.R. 2020. Amphibian Species of the World: an Online reference. Version 6.0. Available from http://research.amnh.org/herpetology/amphibia/index.html [accessed 6 Feb. 2020]. 
Glaw F. \& Vences M. 2007. A field guide to the amphibians and reptiles of Madagascar. Third Edition. Cologne, Frosch Verlag.

Goris R.C. \& Maeda N. 2004. Guide to the Amphibians and Reptiles of Japan. Malabar, Florida, Krieger Publishing Company.

Harvey M.B., Pemberton A.J. \& Smith E.N. 2002. New and poorly known parachuting frogs (Rhacophoridae: Rhacophorus) from Sumatra and Java. Herpetological Monographs 16 (1): 46-92. https://doi.org/10.1655/0733-1347(2002)016[0046:NAPKPF]2.0.CO;2

Huelsenbeck J.P. \& Hillis D.M. 1993. Success of phylogenetic methods in the four taxon case. Systematic Biology 42: 247-264. https://doi.org/10.1093/sysbio/42.3.247

IUCN 2020. The IUCN Red List of Threatened Species. Version 2020-1. Available from https://www.iucnredlist.org. [accessed 19 Mar. 2020].

Jiang D., Jiang K., Ren J., Wu J. \& Li J. 2019. Resurrection of the genus Leptomantis, with description of a new genus to the family Rhacophoridae (Amphibia: Anura). Asian Herpetological Research 10: 1-12. https://doi.org/10.16373/j.cnki.ahr.180058

Jiang K., Wang K., Yang J., Jin J., Zou D., Yan F., Pan H. \& Che J. 2016. Two new records of amphibia from Tibet, China, with decription of Rhacophorus burmanus [In Chinese with English abstract]. Sichuan Journal of Zoology 35 (2): 210-216.

Katoh K. \& Standley D.M. 2013. MAFFT multiple sequence alignment software version 7: improvements in performance and usability. Molecular Biology and Evolution 30: 772-780.

https://doi.org/10.1093/molbev/mst010

Keller A., Rödel M.O., Linsenmair K.D. \& Grafe T.U. 2009. The importance of environmental heterogeneity for species diversity and assemblage structure in Bornean stream frogs. Journal of Animal Ecology 78: 305-314. https://doi.org/10.1111/j.1365-2656.2008.01457.x

Kuraishi N., Matsui M., Hamidy A., Belabut D.M., Ahmad N., Panha S., Sudin A., Yong H.S., Jiang J.P., Ota H., Thong H.T. \& Nishikawa K. 2013. Phylogenetic and taxonomic relationships of the Polypedates leucomystax complex (Amphibia). Zoologica Scripta 42 (1): 54-70.

https://doi.org/10.1111/j.1463-6409.2012.00562.x

Leaché A.D. \& Reeder T.W. 2002. Molecular systematics of the eastern fence lizard (Sceloporus undulatus): a comparison of parsimony, likelihood, and Bayesian approaches. Systematic Biology 51: 44-68. https://doi.org/10.1080/106351502753475871

Li J.T., Che J., Bain R.H., Zhao E.M. \& Zhang Y.P. 2008. Molecular phylogeny of Rhacophoridae (Anura): A framework of taxonomic reassignment of species within the genera Aquixalus, Chiromantis, Rhacophorus, and Philautus. Molecular Phylogenetics and Evolution 48 (1): 302-312.

https://doi.org/10.1016/j.ympev.2008.03.023

Li J.T., Liu J., Chen Y.Y., Wu J.W., Murphy R.W., Zhao E.M., Wang Y.Z. \& Zhang Y.P. 2012a. Molecular phylogeny of treefrogs in the Rhacophorus dugritei species complex (Anura: Rhacophoridae), with descriptions of two new species. Zoological Journal of the Linnean Society 165 (1): 143-162.

https://doi.org/10.1111/j.1096-3642.2011.00790.x

Li J.T., Li Y., Murphy R.W., Rao D.Q. \& Zhang Y.P. 2012b. Phylogenetic resolution and systematics of the Asian tree frogs, Rhacophorus (Rhacophoridae, Amphibia). Zoologica Scripta 41 (6): 557-570. https://doi.org/10.1111/j.1463-6409.2012.00557.x

Liang Y.S. \& Wang C.S. 1978. A new tree frog Rhacophorus taipeianus (Anura: Rhacophoridae) from Taiwan (Formosa). Quarterly Journal of the Taiwan Museum 31: 185-202. 
Liu C. 1950. Amphibians of western China. Fieldiana Zoology Memoires 2: 1-397.

Liu B.-Q., Wang K., Jiang H.M., Chen J.J., Zhou J.N., Xu \& Wu C.H. 2017. A new treefrog species of the genus Rhacophorus Found in Zhejiang, China (Anura: Rhacophoridae) [In Chinese with English abstract]. Chinese Journal of Zoology 52: 361-372.

Lue K.Y., Lai J.S. \& Chen S.L. 1994. A new species of Rhacophorus (Anura: Rhacophoridae) from Taiwan. Herpetological 50: 303-308.

Lue K.Y., Lai J.S. \& Chen S.L. 1995. A new species of Rhacophorus (Anura: Rhacophoridae) from Taiwan. Journal of Herpetology 29: 338-345.

Maeda N. \& Matsui M. 1990. Frogs and Toads of Japan. Second Edition. Bun-ichi Sogo Shuppan. Tokyo.

Matsui M., Kawahara Y., Nishikawa K., Ikeda S., Eto K. \& Mizuno Y. 2019. Molecular phylogeny and evolution of two Rhacophorus species endemic to mainland Japan. Asian Herpetological Research 10 (2): 86-104. https://doi.org/10.16373/j.cnki.ahr.190015

Mo Y.M., Chen W.C., Liao X.W. \& Zhou S.C. 2016. A new species of the genus Rhacophorus (Anura: Rhacophoridae) from southern China. Asian Herpetological Research 7 (3): 139-150.

https://doi.org/10.16373/j.cnki.ahr.150070

Nguyen Q.T., Pham T.C., Nguyen T.T., Ngo N.H. \& Ziegler T. 2016. A new species of Theloderma (Amphibia: Anura: Rhacophoridae) from Vietnam. Zootaxa 4168 (1): 171-186.

https://doi.org/10.11646/zootaxa.4168.1.10

Nguyen T.T., Matsui M. \& Eto K. 2015. Mitochondrial phylogeny of an Asian tree frog genus Theloderma (Anura: Rhacophoridae). Molecular Phylogenetics and Evolution 85: 59-67.

https://doi.org/10.1016/j.ympev.2015.02.003

Nguyen T.T., Pham T.C., Nguyen Q.T., Ninh T.H. \& Ziegler T. 2017. A new species of Rhacophorus (Amphibia: Anura: Rhacophoridae) from Vietnam. Asian Herpetological Research 8: 221-234. https://doi/10.16373/j.cnki.ahr.170046

Ohler A. 2009. Rhacophorus burmanus (Anderson, 1939) the valid nomen for Rhacophorus taroensis Smith, 1940 and Rhacophorus gongshanensis Yang \& Su, 1984. Herpetozoa 21: 179-182.

Ohler A., Marquis O., Swan S. \& Grosjean S. 2000. Amphibian biodiversity of Hoang Lien Nature Reserve (Lao Cai Province, northern Vietnam) with description of two new species. Herpetozoa 13 (1/2): 71-87.

Orlov N.L., Lathrop A., Murphy R.W. \& Ho C.T. 2001. Frogs of the family Rhacophoridae (Anura: Amphibia) in the northern Hoang Lien Mountains (Mount Fan Si Pan, Sa Pa District, Lao Cai Province), Vietnam. Russian Journal of Herpetology 8: 17-44.

Pan T., Zhang Y., Wang H., Wu J., Kang X., Qian L., Li K., Zhang Y., Chen J., Rao D., Jiang J. \& Zhang B. 2017. A New Species of the Genus Rhacophorus (Anura: Rhacophoridae) from Dabie Mountains in East China. Asian Herpetological Research 8: 1-13. https://doi.org/10.16373/j.cnki.ahr.160064

Rambaut A. \& Drummond A. 2009. TRACER. version 1.5. Available from http://beast.bio.ed.ac.uk/ Tracer [accessed 8 Jul. 2020].

Rao D.Q., Wilkinson J.A. \& Liu H.N. 2006. A new species of Rhacophorus (Anura: Rhacophoridae) from Guangxi Province, China. Zootaxa 1258: 17-31. https://doi.org/10.5281/zenodo.173113

Sengupta S. \& Ahmed M.F. 2017. Distribution of Rhacophorus burmanus (Andersson, 1939), with notes on its natural history. Herpetozoa 29 (3/4): 194-198. 
Simmons J.E. 2002. Herpetological collecting and collections management. Revised edition. Society for the Study of Amphibians and Reptiles. Herpetological Circular 31: 1-153.

Sano N., Kurabayashi A., Fujii T., Yonekawa H. \& Sumida M. 2004. Complete nucleotide sequence and gene rearrangement of the mitochondrial genome of the bell-ring frog, Buergeria buergeri (family Rhacophoridae). Genes \& Genetic Systerm 79: 151-163. https://doi.org/10.1266/ggs.79.151

Stejneger L. 1907. Herpetology of Japan and adjacent territory. Bulletin of the United States National Museum 58, Governement Printing Office, Washington.

Sterling E.J., Hurley M.M. \& Le M.D. 2006. Vietnam: A Natural History. Yale University, New Haven.

Tanabe A.S. 2011. Kakusan 4 and Aminosan: two programs for comparing nonpartitioned, proportional and separate models for combined molecular phylogenetic analyses of multilocus sequence data. Molecular Ecology Resources 11: 914- 921. https://doi.org/10.1111/j.1755-0998.2011.03021

Tavaré S. 1986. Some probabilistic and statistical problems in the analysis of DNA sequences. Lectures on Mathematics in the Life Sciences 17: 57-86.

Wilkinson J. 2003. Kinugasa flying frog, Rhacophorus arboreus. Grzimek's Animal Life Encyclopedia 6: 299 .

Wilkinson J.A. \& Rao D. 2004. Taxonomic status of Rhacophorus taronensis Smith, 1940. Proceedings of the California Academy of Sciences, San Francisco 55 (25): 451-457.

Yu G., Hui H., Hou M., Wu Z., Rao D.Q. \& Yang J.X. 2019. A new species of Zhangixalus (Anura: Rhacophoridae), previously confused with Zhangixalus smaragdinus (Blyth, 1852). Zootaxa 4711: 275-292 https://doi.org/10.11646/zootaxa.4711.2.3

Ziegler T., Tran D.T.A., Nguyen T.Q., Perl R.G.B., Wirk L., Kulisc M., Lehmann T., Rauhaus A., Nguyen T.T., Le Q.K. \& Vu T.N. 2014. New amphibian and reptile records from Ha Giang Province, northern Vietnam. Herpetology Notes 7: 185-201.

Manuscript received: 19 November 2019

Manuscript accepted: 3 June 2020

Published on: 21 July 2020

Topic editor: Rudy Jocqué

Desk editor: Marianne Salaün

Printed versions of all papers are also deposited in the libraries of the institutes that are members of the EJT consortium: Muséum national d'Histoire naturelle, Paris, France; Botanic Garden Meise, Belgium; Royal Museum for Central Africa, Tervuren, Belgium; Royal Belgian Institute of Natural Sciences, Brussels, Belgium; Natural History Museum of Denmark, Copenhagen, Denmark; Naturalis Biodiversity Center, Leiden, the Netherlands; Museo Nacional de Ciencias Naturales-CSIC, Madrid, Spain; Real Jardín Botánico de Madrid CSIC, Spain; Zoological Research Museum Alexander Koenig, Bonn, Germany; National Museum, Prague, Czech Republic. 
Appendix 1. Specimens examined for morphological comparisons.

\section{Zhangixalus dennysi}

VIETNAM • 4 đ̊, 2 P; Vinh Phuc Pronvince, Me Linh District; ML.2019.1, ML.2019.2, VNMN 06188, IEBR 132, IEBR 133, IEBR 134•1 q; Tuyen Quang Province, Cham Chu Nature Reserve; TQ.2019.100.

\section{Zhangixalus dorsoviridis}

VIETNAM • 3 §̧; Lao Cai Province, Y Ty District; VNMN 04314, VNMN 04331, VNMN 04343 • 1 क ; Lai Chau Province, Sin Ho District; VNMN 05858.

\section{Zhangixalus duboisi}

VIETNAM • 1 +, 1 đ; Lai Chau Province: Phong Tho District; VNMN 010238, VNMN 010239 • 2 đ; Ha Giang Province, Quan Ba District; VNMN 07069, VNMN 07070.

\section{Zhangixalus dugritei}

CHINA・ 2 §̊; Sichuan; CIB 20050194, KUHE 27701.

\section{Zhangixalus puerensis}

VIETNAM • 2 +, 1 §̧; Lai Chau Province, Phong Tho District; VNMN 010288, VNMN 010289, VNMN 010293.

\section{Zhangixalus pachyproctus}

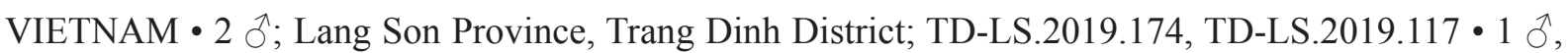
1 क; Thanh Hoa Province, Xuan Lien National Park; XL.2013.2, XL.2013.4 • 1 đ̃; Tuyen Quang, Cham Chu Nature Reserve; TQ.2019.85・1 §̧; Lao, Hua Phan District; VNMN 06405. 